\title{
Building a School Energy Policy - A Review Paper
}

\author{
Ibrahim Can Korkuta \\ Prof, Dr Shyqyri Llacib \\ a PhD Candidate, Faculty of Business Administration, Epoka University, Tirana, Albania \\ bProf, Dr, Faculty of Economy, Tirana University, Tirana, Albania \\ Email: ickorkut13@epoka.edu.al, shyqyrillaci@feut.edu.al
}

Doi:10.5901/jesr.2016.v6n2p183

\begin{abstract}
Human has always searched for higher living standards and greater power. Higher energy consumption, conversion, quality and efficiency have greatly served for the purpose with some consequences. Yet, the energy crisis in 1970s forced countries to take more imposing and complicated measures for energy saving and efficiency. For instance, the European Union set forward the 2010 Energy Performance of Buildings Directive legislation to lessen building energy consumption. The International Energy Agency (IEA) proposed its '25 Energy Efficiency Policy Recommendations' in 2008 to save energy and to reduce annual $\mathrm{CO} 2$ emissions. Education and energy are two key concepts in people's life. As schools play a significant role in education, they can play a similar role in energy consumption and education. Millions of students are enrolled in pre-primary, primary and secondary education around the world every year and countries spend significant amount of their GDP on education. It provides great opportunities to governments and schools to reduce energy consumption, save environment, and teach future generations the importance of building/following policies and standards through education as energy policy and education in schools have become an applying issue in today's world and for the future. The aim of this article is to emphasize the importance of energy users' behavior, school energy education and policies as building and implementing a school energy policy with the help of energy education and (inter)national standards can pay off not only within school areas but also nationwide in the long run. Additionally, this article provides step-by-step energy policy guidance with a sample primary school energy policy for schools from the beginning and recommendations to raise school members' energy awareness.
\end{abstract}

Keywords: School, energy users' behavior, school energy education, school energy policy

\section{Significance of School Energy Policy}

Energy policy is a means of determining how energy will be produced, contributed and consumed. It is derived from energy conservation guidelines, public concerns, state legislation, taxation, international agreements, environmental issues and investment encouragement. U.S. Department of Energy defines energy policy as "An energy policy establishes and validates top management's commitment to energy performance improvement. It must be defined by top management, as well as documented and understood by employees and anyone working on behalf of the organization" (U.S. Department of Energy, 2015).

Although The European Union's interest in energy efficiency and policy started with energy crisis due to dramatically increased oil prices in the 70s with some poorly implemented energy directives, in 1989 the first uses of The TERMIE program that provided energy technologies was a milestone and the original SAVE program was approved in 1991 (Allard \& Seppanen, 2009). The 1998's action plan recommended the Union Members 1\% additional energy efficiency improvement higher than expectations. The European Union announced its first mandatory energy policy in 2005 followed by "Energy for a Changing World" policy in January 2007 and EU obligatory 20/20/20 energy policy objectives in March 2007 (Obrecht et al., 2013). The leaders of the Union agreed in March 2007 to reduce the EU's projected energy consumption by $20 \%$ by 2020 . That is the equivalent of closing 400 power stations. In 2011 , the Union proposed an energy efficiency plan up to the year 2050 and in 2012, an energy efficiency directive for indicative energy efficiency targets (EUR-Lex, 2015). In October 2014, the Union leaders agreed on a higher energy savings target of 27 $\%$, or greater, by 2030.

On a national scale -depending on the country in accordance with the constitution, relevant directives and international treaties- a national energy policy basically aims at:

- Increasing energy efficiency, energy reliability and job opportunities 
- Reducing pollution, energy prices and energy import.

American Council for an Energy-Efficient Economy (ACEEE) explain that "The opportunities for realizing these energy efficiency savings are distributed throughout many end-uses, from manufacturing systems to transportation choices to home appliances. Federal policies that promote efficient investment in each sector and end-use are critical to tackling climate change, economic development, and job creation" (American Council for an Energy-Efficient Economy, 2015). Variant energy agencies help to develop energy policy and efficiency throughout the world. Energy Star in U.S., European Environment Agency (EEA) in The European Union and International Energy Agency (IEA) in 28 OECD countries support their members in this meaning by making recommendations and building standards. For instance, IEA 25 Energy Policy Recommendations booklet (International Energy Agency, 2011) summarizes a set of 25 energy efficiency policy recommendations developed in 2008 for seven priority areas. It was calculated that if the proposal was implemented globally without delay, it would save countries 1 trillion USD in energy and reduce annual CO2 emissions by the equivalent of about 1.5 times recent annual emissions in the United States from the energy sector (Pasquier, 2013). According to Energy Policy Review of Indonesia (International Energy Agency, 2008), two of IEA's International Energy Programme's targets are "to promote rational energy policies in a global context through co-operative relations with non-member countries, industry and international organizations" and "to assist in the integration of environmental and energy policies".

Schools are one of the most commonly used buildings all over the world and almost everybody spends a great amount of their life time at schools. About 1398 million students were enrolled in pre-primary, primary and secondary education around the world in 2010 (The World Bank, 2016) and the number is equal to the population of China in 2013. With the number of their participants and purpose, schools play a significant role in bringing up children and shaping their characters and habits. Schools also play an important role on energy consumption with their increasing energy costs as the world population and use of energy consuming appliances keep growing. According to the World Bank, on the global scale, countries spend $4.77 \%$ of their GDP only on primary education on average (The World Bank, 2016). The European Union 'allocates $6.4 \%$ of their total public expenditure to direct public-sector support for pupils and students in all education levels' (European Commission, 2012). Additionally, annual energy expenditure of primary and secondary school in U.S. is higher than 6 billion dollars (Orth, 2009).

Huge energy consumption and costs along with environmental consequences make school energy management an alarmingly important issue. Thus, the issue naturally attracts scientific attention. Starting from Stanley (Stanley, 1957) up to now researchers emphasized the importance, effectiveness, implementations of school policies, staff's and communities' involvement, effects of policy outcomes, interrelation between environmental issues and school energy policies, policy enactment and implementation and the role of policy actors in policy (Lane et al., 2014). Stanley (Stanley, 1957) advocated the importance of involving different school and community members in policy progress. Bandura (Bandura, 1986) investigated energy saving behaviors while Bontrager and Hubbard (1977) highlighted the significance of school energy policies from the point of energy crisis as schools consume great amount of energy. Hines et al. (1987) along with DeWaters and Powers (2011) focused on environmental behaviors. Braun et al. (2010) carried out a study on school policy performance and Ball et al. (2011) researched policy actors' roles. Although there are many other researches in the field, there is a lot of space for scientific studies on school energy policy.

The U.S. Environmental Protection Agency (EPA) (U.S. Environmental Protection Agency, 2005) states that organizations with energy management policies show better performance than the ones without policies. U.S. Department of Energy - by the applications of Energy Smart Schools Program - concludes that schools can save energy up to $25 \%$ through efficient management and school energy policies supported by distribution of information and guidelines (U.S. Department of Energy, 2009). It is clear that school energy policies make difference and show better energy performance. The U.S. Department of Energy counts the benefits of high performance schools in its Guide to Operating and Maintaining EnergySmart Schools (U.S. Department of Energy, 2009) as:

- Value to the Community: Quality schools attract businesses

- Educational Value: High-performing schools are educational tools to teach significance of energy efficiency to future generations

- Student/Teacher Health and Satisfaction: Indoor air quality, lighting and thermal comfort increases students' outcome and attendance

- Operational/Financial: EnergySmart Schools reduce energy cost and they are more systematic to run.

Environmental benefits due to less carbon footprints and depletion of natural resources should also be added to the above-mentioned list.

Ministries related to energy and education, and schools are to find means of increasing energy 
efficiency/performance and reducing energy use and costs. Successfully implemented school energy policies supported with energy education can serve for the purpose. Rickert (Rickert, 2011) proposes that administrators, energy resource managers and teachers should be involved in both strategies. Lane et al. (2014) recommend a school energy policy and energy education as two basic precautions for energy efficiency in schools. To harvest the best results, these two precautions should be combined by making energy education a significant partition in school energy policy. Many energy management and efficiency projects may fail in practice even though they seem effective in theory. One of the reasons behind those failures is unforeseen energy users' behavior and lack of energy education as it is people who use energy in real life not the policy makers or managers.

\section{Impact of Energy Users' Behavior}

Users' behavior affects energy efficiency (Salleh et al., 2014) and energy consumption patterns (Heiskanen, 2013) in buildings. Energy consumption analysis without taking energy users' behavior will not be realistic as Masoso and Grobler's study (2010) evidenced that energy is wasted in buildings even they are not occupied. McKinsey (2009) found cost effective energy users' behavior may reduce energy consumption by $22 \%$ and low-cost and no-cost energy consumption/efficiency measurements by $57 \%$. The same research found out that people adapt to energy efficient technology fast if monetary savings are obvious in particular. It applies to school buildings as well since users' behavior can influence energy conservation up to $15 \%$ in schools (Ismail, 2009) indicating the importance of users' behavior on energy conservation alone in school buildings. For instance, up to 900 million dollars can be saved through proper energy user behavior only in primary and secondary schools in U.S. as they spend 6 billion dollars yearly on energy bills (Orth, 2009).

Salleh et al. (2014) draw attention to questionnaire surveys on "building users as respondents with the aim of investigating the relationship between user behaviors with building design in evaluating school building design" and observatory method on "user perception assessment in the building can provide information on the user performance and satisfaction level". European Union's goal to base energy consumption on users' needs makes energy users' behavior a more central issue. The challenge is that although energy efficiency is considered as the key indicator for energy consumption, it is not the same as for the users. Except for simply saving energy in some ways, energy users should be able to understand and deal with the issue more conscientiously which requires knowledge of energy users' behavior. After this initial step, the case should be dealt from the point of improving energy users' behavior and building designs accordingly. An optimum/effective method should be practiced that matches energy efficiency - including users' comfort and environmental issues -, users' behavior and building design. Energy efficiency specialists should first understand users' behavior (Parnell \& Popovics-Larsen, 2005) as often building energy efficiency practices do not answer users' demands and they should take realities into account which limit the success of efficiency measures (Heiskanen \& Lovio, 2010). Firstly, it is to be stated that energy use is the result of other purposes rather than simply the act of energy use. Thus, those concerns should be dealt with the help of various insiders and more measurable and automatic systems. A good example of taking users' perception into account is Low Carbon Communities Challenge's implementation in United Kingdom that observes energy users' reaction to new energy conservation measurements (Department of Energy and Climate Change, 2010).

Naturally students' behavior involvement in energy consumption in schools is limited in comparison with their behavioral impacts at homes. Yet, energy consumption/efficiency education at schools will help to develop better understanding of energy use and efficiency in every field during the course individual's life.

\section{Need for Energy Education in Schools}

As everything stands on knowledge and turns around energy, they play a crucial role for human race. Thus, energy education is a significant component for the future and school energy education is an important part of school energy policy. However, energy education in schools should not be proposed or taken as a pure school subject or an issue mentioned only by science teachers. Rather, it should be considered as a tool to enhance life standards of individuals and societies. It will be more fruitful if the concept is practiced within and outside schools. Student-centered energy education that is based on practice rather than theory is more likely to attract students' attention.

A step-by-step energy education can be implemented starting from motivational presentations by students and some experts of the field according to students' levels. School science fairs concerning energy, energy use and saving, energy and environment, etc. can attract students' and staff's attention to take part in energy savings and efficiency and 
prompt them to take more actions specifically if they are rewarded with success and participation certificates. Lectures and regular competitions such as an informative poster competition can refresh students' attention in the matter. Furthermore, building a school energy policy team with administrators, teachers, parents, some experts of the field, school workers and students is a good start to take some measures. In-service training by using school facilities as an on-the-walk school energy survey/audit with students and staff can be both practical and informative. School newsletters, website announcements, progress reports in different places of the school and consultative and informative meetings can gain school-wide support. It is understandable that school energy policy teams and schools themselves will need some in-hand educational material for guidance. Alliance to Save Energy's Green Schools Program and the National Energy Education Development Project (National Energy Education Development, 2012) provide free resources to build a plan not only for energy education in schools but also for energy efficiency measures. The measures can vary from turning off lights in unoccupied rooms to upgrading energy consuming systems as schools can adapt their own energy efficiency and policy plans. Moreover, Lane et al. (2014) state that the Wisconsin K-12 Energy Education Program (KEEP), "a statewide energy education program in Wisconsin to promote the development of energy policy and education plans in the state's schools", can be used as a guideline. The program does not only build a plan for the school district but also provides a school energy program framework to be applied.

\section{Building a School Energy Policy}

According to a report from the International Energy Agency that confirms the position of energy efficiency as the world's "first fuel", the total global energy efficiency market is worth at least 310 billion USD a year and growing (International Energy Agency, 2014). Wiel et al. (1998) state that "building energy efficiency policies have played important roles in reducing energy demand and improving energy use in building sector in the Organization for Economic Cooperation (OECD) countries". They also argue that these policies require voluntary agreements and energy efficiency standards. Thus, following (inter)nationally accepted standards, guidelines and successful policy applications can help schools to build their own school energy policies. For instance, U.S. Department of Energy (U.S. Department of Energy, 2015) states that the policy must state management's commitments to;

- Achieving continual improvement in energy performance

- Ensuring availability of information and resources to meet energy objectives

- Complying with legal energy requirements subscribed to by the organization

- Supporting to purchase energy efficient products and services

- Supporting to design energy performance improvement

According to the department, "the policy provides the framework for setting the company's energy objectives and targets and is consistent with the strategic plan" (U.S. Department of Energy, 2015). Thus, energy policy defines the priorities of energy use in an organization combining with the other current policies of the organization.

Additionally, Department for Education and Skills (Department for Education and Skills, 2002) delivers a guide to manage school energy and water. The guide summarizes energy management action plan in several steps as follow:

- Identify of current school energy management through a matrix

- Display the current energy cost

- Assess what and how to improve

- Compare through benchmarking

- Set realistic energy saving/efficiency objectives with low cost or no-cost implementation

- Streamline school accommodation for the best efficiency

- Sustain school energy and energy linked systems

- Compute the economic energy costs

- Instruct and train school members

It is clear that identifying a school energy management plan along with a statement of commitment is the first step for a school energy policy. In this manner, EnergyStar of the U.S. Environmental Protection Agency Program (EnergyStar, 2013) provides a simplified energy management guideline as given below in Figure 1: 


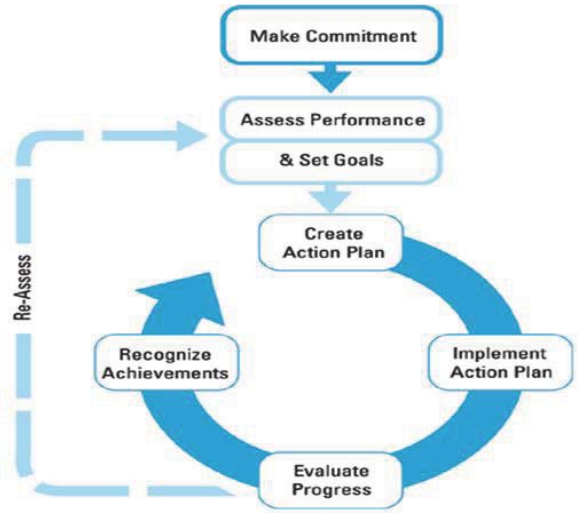

Figure 1. A Simplified Energy Management Guideline by EnergyStar of the U.S. Environmental Protection Agency Program

As mentioned before, inspecting successful samples and a detailed school energy policy matrix is a good start to build a school energy policy. For instance, The Wisconsin K-12 Energy Education Program (KEEP) can be very useful at least to have a practical guideline for a start. As an energy management matrix, the matrix by Energy Management Guide (Building Research Energy Conservation Support Unit, 1993) has been used directly or with some variations by numerous organizations, such as National College for Teaching and Leadership (2015) and by Carbon Trust funded by the UK Department of Energy and Climate Change in the guideline called "A Whole School Approach". It is a five-level matrix with Energy Policy, Organizing, Motivation, Information Systems, Marketing and Investment as evaluating and development variables. Some organizations such as Wiltshire Council (2013) use "Training, Performance Measurement and communicating as variation. The lowest level in the matrix is considered as "no explicit (energy) policy" and the highest one as "energy policy action plan and regular review have active commitment of top management as part of a corporate strategy". An energy and water management matrix for schools recommended by National College for Teaching and Leadership (2015) is given below in Table 1.

Table 1: Energy and water management matrix for schools

\begin{tabular}{|c|c|c|c|c|c|c|}
\hline & $\begin{array}{l}\text { Energy and water } \\
\text { policy }\end{array}$ & $\begin{array}{l}\text { Organising for energy } \\
\text { and water efficiency }\end{array}$ & Education & $\begin{array}{l}\text { Information collection } \\
\text { and analysis }\end{array}$ & Communication & $\begin{array}{l}\text { Investing in energy } \\
\text { and water efficiency }\end{array}$ \\
\hline & \begin{tabular}{|} 
All members of senior \\
management \\
committed to an \\
energy and water \\
policy and action plan; \\
regular reviews as \\
part of the school's \\
SD strategy
\end{tabular} & $\begin{array}{l}\text { Energy and water } \\
\text { management fully } \\
\text { integrated into } \\
\text { management structure; } \\
\text { clear delegation of } \\
\text { responsibility for } \\
\text { management of energy } \\
\text { and water consumption }\end{array}$ & $\begin{array}{l}\text { Full involvement of } \\
\text { learners in the } \\
\text { management of } \\
\text { energy and water in } \\
\text { the school, at a level } \\
\text { appropriate to their } \\
\text { age }\end{array}$ & $\begin{array}{c}\text { Comprehensive } \\
\text { system: setting targets, } \\
\text { monitoring } \\
\text { consumption, } \\
\text { identifying faults, } \\
\text { quantifying savings and } \\
\text { providing budget } \\
\text { tracking }\end{array}$ & $\begin{array}{l}\text { Formal and informal } \\
\text { channels of } \\
\text { communication regularly } \\
\text { explored by energy and } \\
\text { water coordinator, } \\
\text { learners and school } \\
\text { management team }\end{array}$ & $\begin{array}{c}\text { Positive } \\
\text { discrimination in } \\
\text { favour of green } \\
\text { schemes with } \\
\text { investment appraisal } \\
\text { of all new build and } \\
\text { refurbishment } \\
\text { opportunities }\end{array}$ \\
\hline 3 & $\begin{array}{l}\text { Formal energy and } \\
\text { water policy, but with } \\
\text { only a low level of } \\
\text { commitment from } \\
\text { senior management }\end{array}$ & $\begin{array}{l}\text { Energy and water } \\
\text { coordinator accountable } \\
\text { to senior management } \\
\text { and governors }\end{array}$ & $\begin{array}{c}\text { Co-ordinated } \\
\text { approach to energy } \\
\text { and water education, } \\
\text { linked to school policy }\end{array}$ & $\begin{array}{l}\text { Monitoring and } \\
\text { targeting reports for } \\
\text { premises and major } \\
\text { users where possible; } \\
\text { savings not reported } \\
\text { effectively to users }\end{array}$ & $\begin{array}{l}\text { Programme of energy } \\
\text { and water awareness, } \\
\text { including regular } \\
\text { publicity campaigns } \\
\text { aimed at all building } \\
\text { users }\end{array}$ & $\begin{array}{l}\text { Same payback } \\
\text { criteria employed as } \\
\text { for all other } \\
\text { investment }\end{array}$ \\
\hline 2 & $\begin{array}{l}\text { Unadopted energy } \\
\text { and water policy set } \\
\text { by senior } \\
\text { management }\end{array}$ & $\begin{array}{l}\text { Energy and water } \\
\text { coordinator in post but } \\
\text { line management and } \\
\text { authority unclear }\end{array}$ & $\begin{array}{c}\text { Some identification of } \\
\text { opportunities for using } \\
\text { the school buildings } \\
\text { and systems to teach } \\
\text { about energy and } \\
\text { water efficiency }\end{array}$ & $\begin{array}{l}\text { Monitoring and } \\
\text { targeting reports based } \\
\text { on actual meter } \\
\text { readings; analysis of } \\
\text { trends, and input into } \\
\text { budget setting }\end{array}$ & $\begin{array}{l}\text { Some ad hoc } \\
\text { awareness training for } \\
\text { all building users }\end{array}$ & $\begin{array}{l}\text { Investment using } \\
\text { short-term payback } \\
\text { criteria only }\end{array}$ \\
\hline
\end{tabular}




\begin{tabular}{|c|c|c|c|c|c|c|}
\hline 1 & $\begin{array}{c}\text { Energy and water } \\
\text { policy }\end{array}$ & $\begin{array}{c}\text { Organising for energy } \\
\text { and water efficiency }\end{array}$ & Education & $\begin{array}{c}\text { Information collection } \\
\text { and analysis }\end{array}$ & Communication & $\begin{array}{c}\text { Investing in energy } \\
\text { and water efficiency }\end{array}$ \\
\hline Unwritten guidelines & $\begin{array}{c}\text { Energy and water } \\
\text { management } \\
\text { responsibilities identified } \\
\text { but not co-ordinated }\end{array}$ & $\begin{array}{c}\text { Uncoordinated } \\
\text { delivery of energy and } \\
\text { water education in the } \\
\text { school }\end{array}$ & $\begin{array}{c}\text { Annual cost reporting } \\
\text { based only on bill data } \\
\text { with some analysis of } \\
\text { annual trends }\end{array}$ & $\begin{array}{c}\text { Informal contacts used } \\
\text { to communicate school } \\
\text { energy and water } \\
\text { performance and plans } \\
\text { for improvement }\end{array}$ & $\begin{array}{c}\text { Only low-cost } \\
\text { measures taken }\end{array}$ \\
\hline No explicit policy & $\begin{array}{c}\text { No energy or water } \\
\text { managent, nor formal } \\
\text { delegation of } \\
\text { responsibility for } \\
\text { consumption }\end{array}$ & $\begin{array}{c}\text { No known teaching of } \\
\text { energy efficiency or } \\
\text { water conservation }\end{array}$ & $\begin{array}{c}\text { Meter readings not } \\
\text { recorded, bills not } \\
\text { analysed }\end{array}$ & $\begin{array}{c}\text { No communication of } \\
\text { school energy and } \\
\text { water performance }\end{array}$ & $\begin{array}{c}\text { No investment in } \\
\text { increasing energy } \\
\text { and water efficiency } \\
\text { in the school }\end{array}$ \\
\hline
\end{tabular}

Source: National College for Teaching and Leadership, 2015. CSBM Managing the school environment, Section 04: Unit 3: Energy and water management, Utilities management. [Online] Available: https://www.nationalcollege.org.uk/transfer/ open/csbm-managing-the-school-environment/csbm8env-s4/csbm8env-s4t2.html

However, the biggest barrier in front of building a school energy policy and its application is not building an energy management plan but people that find changes difficult to adapt as they feel comfortable in their current state. Moreover, changes usually demand additional effort. Thus, motivation is the key word. Selecting at least two enthusiastic and cooperative members from each diversion of the school such as administrators, custodial workers, teachers, parents and students along with a specialist in the field can make a positive start. Employing an expert/advisor will pay off in the long run although it may be considered as an extra cost at the beginning. Building your own policy with the help of some guidelines, instead of following a totally ready one, can seem difficult at the beginning but the members of the school energy policy team can feel that it is their own work and can more readily stand behind it while they can still make use of some good samples. A set of simplified policy building steps compiled from the relevant literature as given below can be useful as a draft.

- Form a co-operative and enthusiastic school energy policy team including one or two members from each group (administrators, teachers, students, etc.) in addition to a specialist and set regular meetings. Promote team members.

- Apply a school energy audit with the team to evaluate the current state and carry out a SWOT (strengths, weaknesses, opportunities and threats) analysis. Pay attention to energy efficiency.

- Allocate explicit tasks to team members

- Apply an school energy consumption and students' comfort questionnaire at school

- Compile a list of recommendations and feedback from advisors/experts and school members other than the team

- Outline a policy and education plan taking environmental concern into consideration and set targets. Review them at the end of each academic year

- Build a data base

- Arrange in-service training for the team and other school members and encourage them to have relevant certificates such as building or energy management certificates if available

- Follow (inter)national building energy standards and aim at receiving an (inter)nationally accepted building energy certificate

- Publicize outcomes and advocate/lobby school energy policy when you have desirable outcomes

It is also worth mentioning that administrative and financial support is crucial to build and apply a school energy policy. Especially, it will be easier to take and implement decisions if an administrator is a member of the team. Furthermore, by doing so, team members will feel the support of the administration. They will be encouraged and will take the matter more seriously. A sample primary school energy policy (Court Farm Primary School, 2015) approved by a governing body is given below. 


\section{Court Farm Primary School Energy Policy}

\section{Commitment}

Court Farm Primary School is committed to sustainable development and reducing our impacts on the environment. The Governors recognise that energy consumption relating to heating and electricity use within our school releases significant $\mathrm{CO}$ emissions to the environment and we wish to support the targets of the Climate Change Act 2008 by reducing our energy consumption and carbon footprint by $34 \%$ by 2020 . The school is committed to delivering energy and environmental education and will utilize energy management to provide practical learning opportunities across the curriculum and actively involve the whole school community.

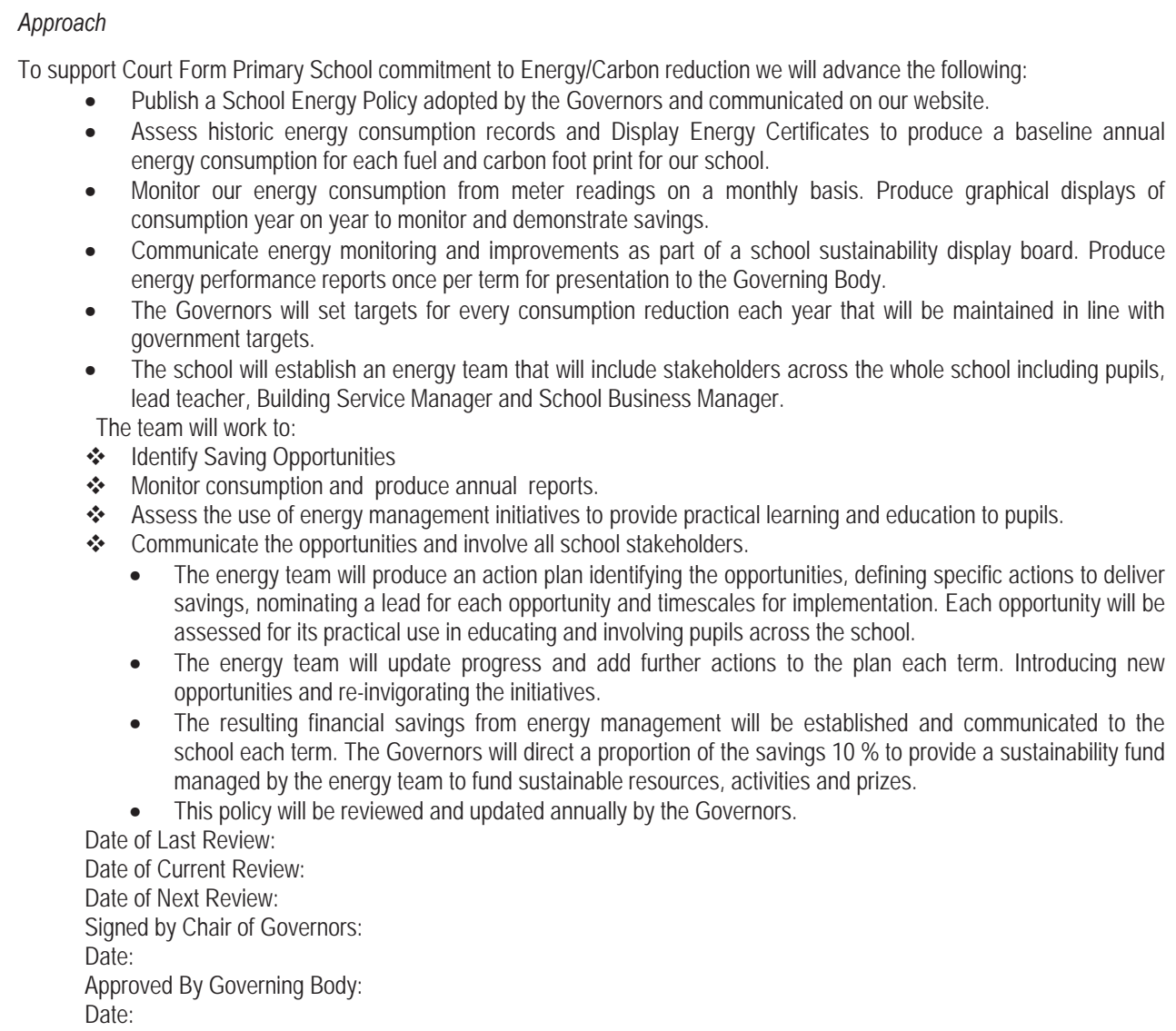

\section{Conclusion}

Energy efficiency is huge and growing market and is presented as the world's first fuel (International Energy Agency, 2014). National and international agencies have put great effort in the matter and have introduced several legislations. However, the issue is so significant that it should be dealt in the bud. Therefore, energy consumption and education should be considered as highly relevant issues not only from the point of reducing energy consumption in schools but also from the point of educating people at the beginning about how to use energy efficiently. Building a school energy policy with the help of energy education at schools can greatly serve for the purpose. Energy education in schools can be more attractive and fruitful if all stakeholders along with students take part in it applying more practical methods, such as school energy audits, surveys on students' energy use behavior, competitions or energy science fairs. Having gained school members attention and built awareness, the next step should be building a school energy policy with the help of a 
school energy policy team and feedback from other school members. A simple but successfully applied policy sample can serve as a starting point and national/international standards/legislations can be taken into consideration in further levels. Signing a contract with an expert or energy company should pay off in the long run.

\section{References}

Allard, F. \& Seppanen, O., 2009. European Actions to Improve Energy Efficiency of Buildings.

American Council for an Energy-Efficient Economy (ACEEE), 2015. National Energy Policy 2015. [Online] Available: http://aceee.org/ portal/national-policy (September 21, 2015)

Ball, S., Maguire, M., Braun, A., \& Hoskins, K., 2011. Policy actors: doing policy work in schools. Discourse: Stud. Cultural Politics Educ. $32(4), 625-639$.

Bandura, A., 1986. Social Foundations of Thought and Action: A Social Cognitive Theory. Prentice-Hall, Englewood Cliffs, NJ.

Bontrager, R., \& Hubbard, C., 1977. A model for education: energy-water consumption decision making. U.S. Department of Health, Education \& Welfare National Institution of Education. Washington, DC.

Braun, A., Maguire, M., \& Ball, S., 2010. Policy enactments in the UK secondary school: examining policy, practice and school positioning. J. Educ. Policy 25 (4), 547-560.

Building Research Energy Conservation Support Unit (BRECSU), 1993. Energy Management Guide: Organisational Aspects of Energy Management, GIR 12, Promoting Energy Efficiency in New Construction. [Online] Available: https://www.energystar.gov/sites/ defaultffiles/buildings/tools/Guidelines\%20for\%20Energy\%20Management\%206_2013.pdf the U.S. Environmental Protection Agency Program (September 12, 2015)

Court Farm Primary School, 2015. Policies-Energy Policies. [Online] Available: http://www.courtfrm.bham.sch.uk/parents/policies (October 12, 2015)

Department for Education and Skills, 2002. Energy and Water Management A Guide for Schools. DfES/0208/2002

Department of Energy and Climate Change (DECC), 2010. Low Carbon Communities Challenge Interim Report 2010/11. Department of Energy and Climate Change, London.

DeWaters, J.E., \& Powers, S.E., 2011. Energy literacy of secondary students in New York State (USA): a measure of knowledge, affect, and behavior. Energy Policy 39 (3), 1699-1710.

EnergyStar, 2013. ENERGY STAR Guidelines For Energy Management. [Online] Available: http://www.energystar.gov/buildings/aboutus/how-can-we-help-you/build-energy-program/guidelines (October 09, 2015)

EUR-Lex, 2015. Energy efficiency for the 2020 goal. [Online] Available: http://eur-lex.europa.eu/legal-content/EN/TXT/?uri=uriserv: en0002 (August 18, 2015)

European Commission, 2012. EACEA; Eurydice; Eurostat, Key Data on Education in Europa 2012. [Online] Available: http://eacea.ec.europa.eu/education/eurydice/documents/key_data_series/134en.pdf (February 27, 2016)

Heiskanen, E., Johnson, M. \& Vadovics, E., 2013. Learning about and involving users in energy saving on the local level. Journal of Cleaner Production Volume 48, June 2013, p. 241-249.

Heiskanen, E., \& Lovio, R., 2010. User Producer Interaction in Housing Energy Innovations: Energy Innovation as a Communication Challenge. Journal of Industrial Ecology 14, 91-102.

Hines, J.M., Hungerford, H., \& Tomera, A., 1987. Analysis and Synthesis of Research on Responsible Environmental Behavior: A metaanalysis. J. Environ. Educ. 18, 1-8.

International Energy Agency (IEA), 2011. 25 Energy Policy Recommendations booklet-Update 2011. [Online] Available: http://www.iea.org/publications/freepublications/publication/25recom 2011.pdf (November 07, 2015)

International Energy Agency (IEA), 2014. Energy Efficiency Market Report 2014, Market Trends and Medium-term Prospects 2013 IEA Statistics, 2015 Edition.

International Energy Agency (IEA), 2008. Energy Policy Review of Endonesia. [Online] Available: http://www.iea.org/publications/free publications/publication/Indonesia2008.pdf) (Septemver 21, 2015)

Ismail, M., Rahman, A.M.A. \& Ismail, M.R., 2009. Field Study On The Ventilation Performance Of The Hybrid Turbine Ventilator (Htv) In The Tropics. International Journal On Design And Manufacturing Technologies, 3.

Lane, J. F., Floress, K., \& Rickert, M., 2014. Development of School Energy Policy and Energy Education Plans: A Comparative Case Study in Three Wisconsin School Communities. Energy Policy 65 (2014) 323-331

Masoso, O. \& L. Grobler, L., 2010. The Dark Side of Occupants' Behavior On Building Energy Use. Energy And Buildings, 42, 173-177.

McKinsey, 2009. Unlocking Energy Efficiency in the U.S. Economy. McKinsey \& Company. July 2009.

National College for Teaching and Leadership, 2015. CSBM Managing the School Environment, Section 04: Unit 3: Energy and Water Management, Utilities Management. [Online] Available: https://www.nationalcollege.org.uk/transfer/open/csbm-managing-theschool-environment/csbm8env-s4/csbm8env-s4t2.html (November 18, 2015)

National Energy Education Development (NEED), 2012. National Energy Education Development Project. [Online] Available: http://www.need.org/ (June 17, 2015)

Obrecht, M. \& Denac, M., 2013. A Sustainable Energy Policy for Slovenia: Considering the Potential of Renewables and Investment Costs. Journal of Renewable and Sustainable Energy 5, 032301.

Orth, K., 2009. Lighting the way. School Planning and Management. [Online] Available: http://www.peterli.com/spm/archive.php? 
article_id=2117 (September 21, 2015)

Parnell, R.\& Popovics-Larsen, O., 2005. Informing the Development of Domestic Energy Efficiency Initiatives. An Everyday Householder-Centred Perspective. Environment and Behaviour 37 (6), 787-807.

Pasquier, S. B., 2013. 25 Ways to Use Less Energy. The Journal of International Energy Agency, Issue 4, Spring 2013.

Rickert, M., 2011. School Energy Policy and Education Plans: A Case Study of Plan Development in Three Wisconsin School Communities. Master's thesis. University of Wisconsin, Stevens Point.

Salleh M.N.M, Kandarb M.Z., Sakipc S.R.Md., \& Johari N., 2014. Users' Perception of Energy Efficiency in School Design. Procedia Social and Behavioral Sciences 170 (2015) 155 - 164

Stanley, W., 1957. The Search for Consensus. Educ. Leadersh. 14 (7), 404-408.

U.S. Department of Energy (DOE), 2015. Energy Efficiency \& Renewable, DOE eGuide For ISO 50001, 2015. [Online] Available: https://ecenter.ee.doe.gov/EM/SPM/Pages/Step1_2_4.aspx (August 19, 2015)

U.S. Department of Energy (DOE), 2009. Energy Smart Schools National Financing Roundtable II - Key Outcomes. Washington, DC.

U.S. Department of Energy (DOE) - Guide to Operating and Maintaining EnergySmart schools. [Online] Available: http://apps1.eere. energy.gov/buildings/publications/pdfs/energysmartschools/ess_0-and-m-guide.pdf (April 16, 2015)

U.S. Environmental Protection Agency, 2005. Teaming Up to Save Energy: Protect Our Environment Through Energy Efficiency. US EPA. Washington, DC (Document no. 430-K-05-007).

Wiel, S., Martin, N., Levine, M., Price, L., \& Sathaye, J., 1998. The Role of Building Energy Efficiency in Managing Atmospheric Carbon Dioxide. Environ. Sci. Policy 1 (1), 27 e38.

Wiltshire Council, 2013. Wiltshire Energy Savers Toolkit for Schools - Introduction and Getting Started. [Online] Available: http://www.wiltshire.gov.uk/get-school-resource-2-energy-savers-toolkit-introduction.pdf (August 17, 2015)

World Bank, 2016. EdStats-Education Statistics-The State of Education. [Online] Available: http://datatopics.worldbank.org/education/ wStateEdu/StateEducation.aspx (Febraury 27, 2016) 
